\title{
PELATIHAN PUBLIC SPEAKING SEBAGAI UPAYA UNTUK MENINGKATKAN RASA PERCAYA DIRI PADA REMAJA KOMUNITAS KAPPAS SURABAYA SURABAYA
}

\author{
Starry Kireida Kusnadi ${ }^{1}$, Nur Irmayanti ${ }^{2}$ Sekaring Ayumeida Kusnadi ${ }^{3}$, Husni Anggoro ${ }^{4}$, \\ Kemilau Senja Berlian Agustina ${ }^{5}$ \\ ${ }^{1}$ Universitas Wijaya Putra \\ ${ }^{2}$ Universitas Wijaya Putra \\ ${ }^{3}$ Universitas Wijaya Putra \\ ${ }^{4}$ Universitas Wijaya Putra \\ ${ }^{5}$ Universitas Wijaya Putra
}

starrykusnadi@uwp.ac.id,nurirmayanti@uwp.ac.id, sekaring@uwp.ac.id, husnianggoro16@gmail.com, kemilausenjaberlian@gmail.com

\begin{abstract}
Abstrak
Bahasa merupakan media berkomunikasi, tercakup semua cara untuk berkomunikasi dimana pikiran dan perasaan dinyatakan dalam bentuk lambang atau simbol untuk mengungkapkan suatu pengertian seperti dengan menggunakan lisan, tulisan, isyarat, bilangan, lukisan, dan mimik muka. Bahasa sebagai alat komunikasi memungkinkan dua individu atau lebih mengekspresikan berbagai ide, arti, perasaan dan pengalaman. Ketidakmampuan berkomunikasi dapat menyebabkan seseorang tidak percaya diri ketika ia tampil didepan umum. Bagi mereka yang memiliki rasa takut untuk berbicara didepan publik, akan muncul rasa panik yang sangat mengganggu pikiran. Sebelum mulai berbicara didepan umum, tubuh yang belum siap akan mulai menunjukkan tanda-tanda awal dari reaksi panik akibat tekanan harus tampil. Salah satu penyebab hal ini terjadi adalah karena kurangnya pengetahuan tentang pidato, latihan dan membiasakan berbicara di depan umum. Tujuan pengabdian ini adalah untuk meningkatkan rasa percaya diri remaja Komunitas Kappas Surabaya melalui pelatihan public speaking. Metode pelaksanaannya adalah pelatihan public speaking pada remaja Komunitas Kappas Surabaya. Diharapkan dengan adanya kegiatan ini para remaja Komunitas Kappas Surabaya dapat memiliki pengetahuan, pemahaman dan keterampilan tentang ilmu public speaking sehingga lebih memahami dan dapat mengaplikasikan teknik berbicara didepan umum. Selain itu rasa percaya diri yang dimiliki menjadi lebih tinggi sehingga remaja Komunitas Kappas Surabaya yakin dengan kemampuannya, optimis, objektif, bertanggungjawab, bertindak rasional dan realistis.
\end{abstract}

Kata Kunci : Public Speaking, Rasa Percaya Diri, Remaja, Komunitas Kappas Surabaya

\section{PENDAHULUAN}

Bahasa merupakan media berkomunikasi dengan orang lain. Tercakup semua cara untuk berkomunikasi, dimana pikiran dan perasaan dinyatakan dalam bentuk lambang atau simbol untuk mengungkapkan suatu pengertian, seperti dengan menggunakan lisan, tulisan, isyarat, 
bilangan, lukisan, dan mimik muka. Bahasa sebagai alat komunikasi memungkinkan dua individu atau lebih mengekspresikan berbagai ide, arti, perasaan dan pengalaman.

Bahasa memegang peranan yang sangat penting dalam kehidupan anak, sebab melalui bahasa anak dapat berkomunikasi dengan lingkungan sekitarnya dan mengungkapkan gagasan atau pikirannya kepada orang lain. Bahasa juga memberikan pengaruh yang besar dalam perkembangan anak. Dengan bahasa anak akan tumbuh dan berkembang menjadi manusia dewasa yang mampu bergaul di tengah-tengah masyarakat. (Handayani, 2008 dalam Hasyim dan D.W, 2014).

Ketidakmampuan berkomunikasi dapat menyebabkan seseorang tidak percaya diri ketika ia tampil didepan umum. Bagi mereka yang memiliki rasa takut untuk berbicara didepan publik, akan muncul rasa panik yang sangat mengganggu pikiran. Saat sebelum mulai berbicara didepan publik, tubuh yang belum siap akan mulai menunjukkan tanda-tanda awal dari reaksi panik akibat tekanan harus tampil. Detak jantung menjadi semakin cepat, telapak tangan mulai berkeringat, saat berdiri kepala terasa pusing dan kedua kaki gemetar. Salah satu penyebab hal ini terjadi adalah karena kurangnya pengetahuan tentang pidato, latihan dan membiasakan berbicara di depan umum (dalam Hasyim dan D.W, 2014).

Wibawa dkk (2012 dalam Hasyim dan D.W, 2014) dalam tulisannya menyatakan bahwa bagi kebanyakan orang, berbicara di depan umum sangat menakutkan. Bahkan ketakutan berbicara di depan umum menduduki rangking yang lebih tinggi dari pada takut pada ketinggian. Situasi ini menggambarkan baik secara langsung maupun secara tidak langsung bahwa berbicara di depan umum merupakan kemampuan yang jika tidak dilatih maka akan menimbulkan gejala psikologis yang hebat pada seseorang yang belum terbiasa berbicara di depan umum.

Dari hasil pengamatan yang dilakukan di Komunitas Kappas Surabaya, remaja memiliki kemampuan public speaking yang rendah sehingga remaja masih belum memahami ilmu public speaking dan teknik berbicara didepan umum yang memadai. Selain itu rasa percaya diri yang dimiliki remaja juga masih rendah, sehingga seringkali masih ragu-ragu, takut salah, kurang berani dalam bertindak dan menyuarakan pendapatnya didepan umum.

Berbicara di depan umum bukan hanya sekedar menyampaikan pesan saja, namun juga memperhatikan bagaimana pesan yang disampaikan dapat dimengerti dan masuk ke dalam hati lawan bicara/audiens (Asriandhini dkk, 2020). Public speaking mengutip dari pendapat Zarefsky merupakan proses komunikasi dalam penyampian pesan yang dilakukan terus menerus bahkan berulang antara yang berbicara dengan yang mendengarkan (Yanti, 2017 dalam Rahmadani, 2021).

Langkah-langkah pentrasferan ilmu public speaking yang akan dilakukan mengikuti penahapan sebuah rencana pembicaraan yang disampaikan Tarigan (2008 dalam Nugrahani dkk, 2012) sebagai berikut: 1) Tahap memilih pokok pembicaraan yang menarik hati. Dalam hal ini, peneliti memberikan materi dasar yang mengarah pada pemahaman remaja untuk memilih topik pembicaraan yang menarik, baik menurut diri sendiri maupun masyarakat pada umumnya. Materi dasar ini adalah pengantar public speaking yang di dalamnya mencakup hakikat keterampilan berbicara, hakikat public speaking, dan teknik sederhana merancang public speaking; 2) Tahap membatasi pokok pembicaraan. Pada tahap ini, remaja diarahkan untuk menyempitkan topik yang akan disampaikan. Peneliti memberi penekanan bahwa topik yang benar dan menarik adalah topik yang sempit dan mendalam; 3) Tahap mengumpulkan bahan-bahan. Tahap ini menekankan adanya upaya untuk mencari referensi yang berhubungan dengan topik yang akan disampaikan kepada audiens. Bahan yang dibutuhkan dapat diakses dari berbagai sumber, seperti berita, informasi orang lain, maupun pengalaman pribadi. Bahan-bahan ini untuk memperkuat data mengenai apa yang disampaikan kepada audiens. Sebagian besar, remaja lebih memilih pengalaman pribadi dan berita di surat kabar sebagai bahan referensi; 4) Tahap menyusun bahan. Pada tahap ini, remaja diarahkan untuk mengembangkan rancangan yang telah disusun. 
Adapun bagian ini meliputi: (a) judul; (b) isi; dan (c) simpulan; 5) Tahap tampil secara percaya diri. Tahap ini merupakan tahap puncak dalam kegiatan public speaking. Pada tahap ini, remaja diminta untuk tampil secara individual menyampaikan pesan yang telah disiapkan kepada audiens. Peserta antusias untuk tampil berbicara. Ketika ada yang tampil, peserta yang belum mendapatkan giliran bertugas menjadi audiens yang mendukung jalannya acara.

Public speaking berfokus pada efektivitas pesan yang disampaikan kepada audiens. Komunikasi efektif dalam public speaking didukung oleh beberapa faktor, diantaranya penguasaan materi, kepercayaan diri, mengelola situasi, mengelola audiens, dan penampilan pembicara yang menarik. Faktor utama kesuksesan dalam public speaking adalah kepercayaan diri. Tantowi Yahya berpendapat bahwa keterampilan ini dipraktikkan dengan memanfaatkan setiap kesempatan. Untuk mendapatkan kepercayaan diri ketika berbicara di depan audiens adalah dengan cara berlatih, tidak ada cara instan untuk mendapatkan kemampuan public speaking (Hojanto, 2016, Wakhyudi, 2019, dalam Asriandhini, 2020).

Kepercayaan diri merupakan salah satu aspek kepribadian yang berupa keyakinan akan kemampuan diri seseorang sehingga tidak terpengaruh oleh orang lain dan dapat bertindak sesuai kehendak, gembira, optimis, cukup toleran, dan bertanggung jawab (Ghufron dan Risnawari, 2010). Kepercayaan diri menurut Lauster (2008 dalam Syam A \& Amri, 2017) merupakan suatu sikap atau keyakinan atas kemampuan diri sendiri, sehingga dalam melakukan tindakan-tindakannya tidak terlalu cemas, merasa bebas untuk melakukan hal-hal yang sesuai dengan keinginan dan tanggung jawab atas perbuatannya, sopan dalam berinteraksi dengan keinginan orang lain, memiliki dorongan prestasi serta mengenal kelebihan dan kekurangan diri sendiri.

Kepercayaan diri merupakan salah satu syarat yang esensial bagi individu untuk mengembangkan aktivitas dan kreativitas sebagai upaya dalam mencapai prestasi. Namun demikian, kepercayaan diri tidak tumbuh dengan sendirinya. Kepercayaan diri tumbuh dari proses interaksi yang sehat di lingkungan sosial individu dan berlangsung secara kontinu dan berkesinambungan. Rasa percaya diri tidak muncul begitu saja pada diri seseorang, ada proses tertentu di dalam pribadinya sehingga terjadilah pembentukan rasa percaya diri (Hakim, 2002 dalam Riyanti, C., \& Darwis, R.S, 2020). Menurut Mardatillah (2010 dalam Riyanti, C., \& Darwis, R.S, 2020) seseorang yang memiliki kepercayaan diri tentunya memiliki cir-ciri, yakni: 1) mengenal dengan baik kekurangan dan kelebihan yang dimilikinya lalu mengembangkan potensi yang dimilikinya; 2) membuat standar atas pencapaian tujuan hidupnya lalu memberikan penghargaan jika berhasil dan bekerja lagi jika tidak tercapai; 3) tidak menyalahkan orang lain atas kekalahan atau ketidakberhasilannya namun lebih banyak introspeksi diri sendiri; 4) mampu mengatasi perasaan tertekan, kecewa, dan rasa ketidakmampuan yang menghinggapinya; 5) mampu mengatasi rasa kecemasan dalam dirinya; 6) tenang dalam menjalankan dan menghadapin segala sesuatunya; 7) berpikir positif; dan 8) maju terus tanpa harus menoleh ke belakang.

Menurut Lauster (2008 dalam Riyanti, C., \& Darwis, R.S, 2020) ada beberapa aspek dari kepercayaan diri yakni: 1) keyakinan akan kemampuan diri yaitu sikap positif seseorang tentang dirinya bahwa dia mengerti sungguhsungguh akan apa yang dilakukannya; 2) optimis yaitu sikap positif seseorang yang selalu berpandangan baik dalam menghadapi segala hal tentang diri, harapan dan kemampuan; 3) obyektif yaitu orang yang percaya diri memandang permasalahan atau segala sesuatu sesuai dengan kebenaran semestinya, bukan menurut kebenaran pribadi; 4) bertanggung jawab yaitu kesediaan seseorang untuk menanggung segala sesuatu yang telah menjadi konsekuensinya; dan 5) rasional dan realistis yaitu analisa terhadap suatu masalah, suatu hal, sesuatu kejadian dengan menggunakan pemikiran yang diterima oleh akal dan sesuai dengan kenyataan.

\section{METODE}


Metode pelaksanaan yang digunakan adalah memberikan edukasi tentang pelatihan public speaking kepada remaja Komunitas Kappas Surabaya.

Tahap persiapan. Pada tahap ini peneliti melakukan observasi dan wawancara kepada remaja Komunitas Kappas Surabaya. Peneliti memberikan pretest tentang public speaking untuk mengetahui seberapa besar pengetahuan dan pemahaman tentang public speaking yang dimiliki. Dan memberikan pretest tentang kepercayaan diri untuk mengetahui tinggi atau rendahnya kepercayaan diri yang dimiliki. Peneliti kemudian mempersiapkan materi pelatihan public speaking dan materi edukasi tentang kepercayaan diri.

Tahap pelaksanaan. Pada tahap ini pelatihan public speaking dilaksanakan. Dalam pelatihan ini, strategi yang dipilih adalah strategi kronologis. Strategi ini dilakukan dengan cara memberikan sesuatu secara bertahap, mulai dari yang ringan, hingga pada tahap yang lebih berat. Adapun langkah-langkah pentrasferan ilmu public speaking yang akan dilakukan mengikuti penahapan sebuah rencana pembicaraan yang disampaikan Tarigan (2008 dalam Nugrahani dkk, 2012) dan dikolaborasikan dengan ide peneliti, sebagai berikut: 1) Tahap memilih pokok pembicaraan yang menarik hati. Dalam hal ini, peneliti memberikan materi dasar yang mengarah pada pemahaman remaja untuk memilih topik pembicaraan yang menarik, baik menurut diri sendiri maupun masyarakat pada umumnya; 2) Tahap membatasi pokok pembicaraan. Pada tahap ini, remaja diarahkan untuk menyempitkan topik yang akan disampaikan. Peneliti memberi penekanan bahwa topik yang benar dan menarik adalah topik yang sempit dan mendalam; 3) Tahap mengumpulkan bahan-bahan. Tahap ini menekankan adanya upaya untuk mencari referensi yang berhubungan dengan topik yang akan disampaikan kepada audiens. Bahan yang dibutuhkan dapat diakses dari berbagai sumber, seperti berita, informasi orang lain, maupun pengalaman pribadi. Bahan-bahan ini untuk memperkuat data mengenai apa yang disampaikan kepada audiens; 4) Tahap menyusun bahan. Pada tahap ini, remaja diarahkan untuk mengembangkan rancangan yang telah disusun. Adapun bagian ini meliputi: (a) judul; (b) isi; dan (c) simpulan. Peneliti memberikan kesempatan kepada remaja untuk membuat bahan/materi yang akan ditampilkan; 5) Tahap tampil secara percaya diri. Tahap ini merupakan tahap puncak dalam kegiatan public speaking. Pada tahap ini, remaja diminta untuk tampil secara individual menyampaikan pesan yang telah disiapkan kepada audiens.

Tahap evaluasi. Tahap ini adalah tahap terakhir dalam kegiatan pelatihan public speaking. Setelah remaja tampil di depan forum, peneliti memberi masukan dan penguatan atas penampilan remaja.

\section{HASIL DAN PEMBAHASAN}

Hasil penelitian menunjukkan adanya peningkatan kepercayaan diri remaja Komunitas Kappas Surabaya dengan menggunakan pelatihan public speaking. Remaja Komunitas Kappas Surabaya lebih memiliki pemahaman, pengetahuan dan keterampilan tentang public speaking sehingga remaja dapat mempraktikkan teknik berbicara didepan umum dengan tepat. Selain itu rasa percaya diri yang dimiliki remaja menjadi lebih tinggi sehingga remaja Komunitas Kappas Surabaya lebih yakin dengan kemampuan yang dimilikinya, memiliki sikap yang lebih optimis, berpikir dengan objektif, bertanggungjawab, bertindak dengan rasional dan realistis. Selain itu hal ini juga bisa menunjang keberhasilan remaja Komunitas Kappas Surabaya baik di bidang akademik maupun dalam kegiatan berorganisasi. Remaja bisa mengkomunikasikan ide/pendapatnya dan mengajak orang lain untuk melaksanakan ide/pendapat mereka untuk melakukan berbagai kegiatan yang positif.

Hasil penelitian ini sejalan dengan penelitian sebelumnya yang dilakukan oleh Rahmadani, Wahyuni, dan Ekawarna (2021) menunjukkan terdapat pengaruh kepercayaan diri terhadap kemampuan public speaking pada mahasiswa Pendidikan Sejarah Universitas Jambi. Semakin tinggi kepercayaan diri maka akan mengakibatkan kemampuan public speaking semakin tinggi pula. 
Penelitian yang dilakukan oleh Indraswati, Husniati, Ermiana, Widodo, dan Maulyda, M.A (2020) menunjukkan terdapat pengaruh positif dan signifikan kepercayaan diri terhadap kemampuan public speaking mahasiswa prodi PGSD, FKIP, Universitas Mataram.

Selain itu penelitian yang dilakukan oleh Mahsudi, Kurniawan, dan Hesti (2021) menunjukkan bahwa pelatihan ini memberikan pengetahuan, teknik, pengalaman, dan keterampilan public speaking pada siswa untuk mendukung aktivitasnya disekolah dan masyarakat. Hal ini sesuai dengan tujuan Pendidikan Nasional mengenai penguasaan keterampilan 4C yaitu Critical Thinking, Creativity, Collaboration dan Communication. Para siswa menjadi lebih percaya diri, termotivasi dan memiliki antusias untuk berbicara didepan umum.

\section{KESIMPULAN}

Berdasarkan hasil penelitian maka dapat disimpulkan bahwa pelatihan public speaking yang diberikan efektif untuk meningkatkan rasa percaya diri remaja Komunitas Kappas Surabaya.

Berdasarkan hasil penelitian tersebut maka saran-saran praktis yang bisa diberikan kepada remaja Komunitas Kappas Surabaya adalah remaja harus dapat menerapkan ilmu public speaking saat berbicara didepan umum. Karena dengan menerapkan ilmu public speaking tersebut remaja akan dapat berbicara didepan umum dengan baik dan benar.

Selain itu, remaja harus lebih percaya diri sehingga yakin dengan kemampuan yang dimiliki, memiliki sikap yang lebih optimis, objektif, bertanggungjawab, bertindak lebih rasional dan realistis.

\section{UCAPAN TERIMAKASIH}

Ucapan terima kasih disampaikan kepada Surabaya Children Center Cricis dan Remaja Kappas Surabaya selaku mitra yang terlibat dalam pelaksanaan kegiatan Program Pemberdayaan Masyarakat Tahun 2021.
Ucapan terima kasih juga disampaikan kepada Fakultas Psikologi atas dukungan yang diberikan dan kepada LPPM Universitas Wijaya Putra yang telah mendanai penelitian ini.

\section{REFERENSI}

Asriandhini, B., Khasidah, N., Merliana., Kristika, NA., Pramudita. (2020). Pelatihan Dasar Public Speaking Untuk Mengembangkan Keterampilan Penyampaian Informasi dan Kepercayan Diri Bagi Siswa Tunarungu. Jurnal Loyalitas Sosial, 2(2), 71-84. DOI: http://dx.doi.org/10.32493/JLS.v2i2.p71-84. http://openjournal.unpam.ac.id/index.php/JLS/articl e/view/7007/pdf

Ghufron, M. N., \& Risnawati S. R. (2010). Teori-teori Psikologi. Ar Ruz Media : Yogjakarta

Hakim, T. (2002). Mengatasi Rasa Tidak Percaya Diri. Jakarta: Puspa Swara

Handayani, Putri Ayu. (2008). Pentingnya Peningkatan Keterampilan Berbicara Pada Anak Usia Dini Melalui Metode Bercakap-Cakap. Bandung : Sekolah Sekolah Tinggi Keguruan Dan Ilmu Pendidikan.

Hasyim, M., \& D.W irwan. (2014). Pelatihan Public Speaking Pada Remaja Dan AnakAnak Dusun Puluhan, Desa Banyusidi, Pakis, Magelang, Jawa Tengah. Jurnal Inovasi dan Kewirausahaan, 3(2), 96-100.

Hojanto, O. (2016). Public Speaking Mastery. Jakarta: Gramedia Pustaka Utama.

Indraswati, D., Husniati., Ermiana, I., Widodo, A., Maulyda, M.A. (2020). Pengaruh Kepercayaan Diri Dan Kemampuan Komunikasi Terhadap Kemampuan Public Speaking Mahasiswa PGSD. Alhadharah: Jurnal Ilmu Dakwah, 19(1), 115.

DOI: http://dx.doi.org/10.18592/alhadharah.v19i1.3 $342 . \quad$ https://jurnal.uinantasari.ac.id/index.php/alhadharah/article/view/334 $2 / 2120$.

Lauster, Peter. (2008). Tes Kepribadian. Ed. Cet. 8. Jakarta: Bumi Aksara 
Mardatillah. (2010). Pengembangan Diri. STIE Balikpapan: Madani.

Mashudi,T., Kurniawan,R., Hesti,R.M., \& Purwandari, E. (2021). Membangun Kepercayaan Diri Remaja Melalui Pelatihan Public Speaking Guna Menghadapi Era Industry 4.0. Abdi Psikonomi,1(2), 79-88. https://journals2.ums.ac.id/index.php/abdipsikonom i/article/view/214.

https://journals2.ums.ac.id/index.php/abdipsikonom i/article/view/214/89.

Nugrahani, D., Kustantinah, I., Himatu K., Rr. Festi., \& Larasati. (2012). Peningkatan Kemampuan Public Speaking Melalui Metode Pelatihan Anggota Forum Komunikas Remaja Islam. Jurnal Pengabdian Kepada Masyarakat, $3(1), \quad 1-6 . \quad$ https://doi.org/10.26877/edimas.v3i1.246,

http://journal.upgris.ac.id/index.php/edimas/article/view/246/214

Rahmadani, D.N., Wahyuni, A., \& Ekawarna. (2021). Pengaruh Kepercayaan Diri Terhadap Kemampuan Public Speaking pada Mahasiswa Pendidikan Sejarah Universitas Jambi. Jurnal Randai, 2(2), 22-33. DOI: DOI:https://doi.org/10.31258/randai.2.1.p.22-33. https://randai.ejournal.unri.ac.id/index.php/randai/ar ticle/view/20/27.

Rakhmat, J. (2019). Psikologi Komunikasi Edisi Revisi. Bandung: Simbiosa Rekatama Media.

Riyanti, C., \& Darwis, R.S. (2020). Meningkatkan Kepercayaan Diri Pada Remaja Dengan Metode Cognitive Restructuring. Jurnal Pengabdian dan Penelitian Kepada Masyarakat
(JPPM), $\quad 1(1), \quad 111-119 . \quad$ DOI: ttps://doi.org/10.24198/jppm.v1i1.31857. https://jurnal.unpad.ac.id/jppm/article/view/31857/p df.

Syam, A., \& Amri. (2017). Pengaruh Kepercayaan Diri (Self Confidence) Berbasis Kaderisasi Imm Terhadapprestasi Belajar Mahasiswa (Studi Kasus Di Program Studi Pendidikan Biologifakultas Keguruan Dan Ilmu Pendidikan Universitas Muhammadiyah Parepare. Jurnal Biotek 5(1), 87-102. http://journal.uinalauddin.ac.id/index.php/biotek/article/view/3448/3 $\underline{243}$

Tarigan, Henry Guntur. (2008). Menulis sebagai Suatu Keterampilan Berbahasa. Bandung: Penerbit Angkasa.

Wakhyudi, Y. (2019). Kiat Praktis Kuasai Public Speaking, Tips dan Trik Berbicara di Depan Umum dengan Asyik dan Memukau. Yogyakarta: Checklist.

Yanti, R. (2017). Peningkatan Kemampuan Public Speaking melalui Metode Pelatihan Kader pada Organisasi ISKADA. Skripsi. Fakultas Dakwah dan Komunikasi Universitas Islam Negeri Ar-Raniry 